\title{
PENYUSUNAN INSTRUMEN PENILAIAN GURU-GURU IPA KABUPATEN BANYUWANGI
}

\author{
Oleh: \\ An Nuril Maulida Fauziah ${ }^{1}$, Martini², Wahyu Budi Sabtiawan ${ }^{3}$ \\ 1,2,3,Dosen Jurusan IPA FMIPA Unesa \\ 1annurilfauziah@unesa.ac.id
}

\begin{abstract}
Abstrak
Penelitian ini bertujuan untuk mendeskripsikan hasil penyusunan instrumen penilaian guru-guru IPA Kabupaten Banyuwangi . Penelitian ini merupakan penelitian deskriptif yang mendeskripsikan hasil secara kuantitatif serta didukung penjelasan dari data yang telah didapat. Hasil penelitian menunjukkan bahwa instrument penilaian valid dan layak digunakan untuk penilaian dalam proses pembelajaran dari KD yang disebutkan. Kesimpulan dari instrument penilaian yang telah dikembangkan dari 4 kelompok semuanya valid dan layak digunakan.
\end{abstract}

Kata Kunci: Instrumen penilaian, Kevalidan, IPA

\section{Abstract}

This study aims to describe the results of the preparation of assessment instruments of science teachers Banyuwangi District. This research is a descriptive research that describes the results quantitatively and supported explanation of the data that has been obtained. The results of the study indicate that the assessment instrument is valid and feasible to be used for assessment in the learning process of the mentioned KD. The conclusions of the assessment instrument developed from the four groups are all valid and worthy of use.

Keywords: Assesment Instrument, Validation, Science

\section{PENDAHULUAN}

Tiga komponen pada proses belajarmengajar yang saling berkaitan, yaitu what the educators teach, what the students learn, dan what the educators assess harus bersinergis atau berkaitan satu sama lain. Hasil di akhir pembelajaran, harus sesuai dengan apa yang diajarkan guru di kelas, merupakan tuntutan kurikulum yang ada. Tuntutan implementasi kurikulum 2013 adalah proses pembelajaran yang mampu membantu peserta didik mencapai kompetensi sikap, pengetahuan dan keterampilan. Tuntutan merupakan kata lain dari apa yang ingin dinilai, sehingga keterampilan untuk menilai merupakan komponen penting yang harus dimiliki guru dalam menerapkan kurikulum 2013.

Peraturan Menteri Pendidikan dan Kebudayaan No. 66 Tahun 2013 tentang Standar Penilaian Pendidikan, penilaian pencapaian kompetensi pada jenjang pendidikan dasar dan menengah dilaksanakan oleh pendidik, satuan pendidikan, pemerintah dan/atau lembaga mandiri. Penilaian pencapaian kompetensi oleh pendidik dilakukan untuk memantau proses, kemajuan, dan perkembangan pencapaian kompetensi peserta didik sesuai dengan potensi yang dimiliki dan kemampuan yang diharapkan secara berkesinambungan. Penilaian juga dapat memberikan umpan balik kepada pendidik agar dapat menyempurnakan perencanaan dan proses pembelajaran (Kemendikbud, 2014).

Sejalan dengan tuntutas di atas, Ketua MGMP IPA Kabupaten Banyuwangi melayangkan surat pada tanggal 27 Maret 2017, dengan nomor surat 004/104.33/MGMP.IPA/III/2017, yang berisi permohonan pelatihan untuk peningkatan kompetensi guru pada pengajaran IPA kurikulum 2013 edisi revisi 2016, termasuk penyusunan instrumen penilaian. Surat tersebut menjelaskan bahwa guru-guru di Kabupaten Banyuwangi mengalami kesuitan dalam menyusun penilaian untuk KD yang disajikan pada Tabel 1. 
Tabel 1. Kompetensi Dasar dari KI 3 dan KI 4 yang Dimohon untuk Dijadikan Bahan Pelatihan Penyusunan Instrumen Penilaian

\begin{tabular}{|c|c|c|}
\hline \multicolumn{2}{|r|}{ Kompetensi Dasar dari KI 3} & Kompetensi Dasar dari KI 4 \\
\hline 3.4 & $\begin{array}{l}\text { Menganalisis keterkaitan struktur } \\
\text { jaringan tumbuhan dan fungsinya, serta } \\
\text { teknologi yang terinspirasi oleh struktur } \\
\text { tumbuhan }\end{array}$ & $\begin{array}{l}\text { 4.4 Mengomunikasikan teknologi yang } \\
\text { terinspirasi oleh hasil pengamatan } \\
\text { struktur tumbuhan dari berbagai sumber }\end{array}$ \\
\hline 3.8 & $\begin{array}{l}\text { Memahami tekanan zat dan } \\
\text { penerapannya dalam kehidupan sehari- } \\
\text { hari, termasuk tekanan darah, osmosis, } \\
\text { dan kapilaritas jaringan angkut pada } \\
\text { tumbuhan }\end{array}$ & $\begin{array}{l}\text { 4.8 Menyajikan data hasil percobaan untuk } \\
\text { menyelidiki tekanan zat cair pada } \\
\text { kedalaman tertentu, gaya apung, dan } \\
\text { kapilaritas, misalnya dalam batang } \\
\text { tumbuhan }\end{array}$ \\
\hline 3.9 & $\begin{array}{l}\text { Memahami sifat fisika dan sifat kimia } \\
\text { tanah, organisme yang hidup dalam } \\
\text { tanah, dan pentingnya tanah untuk } \\
\text { keberlanjutan kehidupan }\end{array}$ & $\begin{array}{l}4.9 \text { Menyajikan hasil penyelidikan tentang } \\
\text { sifat-sifat tanah dan pentingnya tanah } \\
\text { bagi kehidupan }\end{array}$ \\
\hline 3.1 & $\begin{array}{l}\text { Memahami proses dan produk teknologi } \\
\text { ramah lingkungan untuk keberlanjutan } \\
\text { kehidupan }\end{array}$ & $\begin{array}{l}\text { 4.10 Menyajikan karya tentang proses dan } \\
\text { produk teknologi sederhana yang ramah } \\
\text { lingkungan }\end{array}$ \\
\hline
\end{tabular}

Universitas Negeri Surabaya (Unesa) berkewajiban menyelenggarakan layanan pendidikan di semua tingkat pendidikan, yaitu pendidikan tinggi, sekolah menengah atas, sekolah menengah pertama, sekolah dasar, dan taman kanak-kanak sebagai wujud pelayanan pendidikan. Salah satu wujud nyata pelayanan pendidikan ini adalah kerjasama yang terjalin antara Jurusan IPA FMIPA Unesa dengan MGMP IPA Kabupaten Banyuwangi.

Dengan demikian, Jurusan IPA akan memberikan pendampingan penyusunan instrumen penilaian untuk KD pada Tabel 1. Hasil yang akan dibahas dalam artikel ini adalah validitas instrumen penilaian dan respon peserta pelatihan terhadap kegiatan pelatihan.

\section{METODE PELAKSANAAN}

Pelaksanaan PKM dibagi menjadi tiga tahapan, yaitu tahap persiapan, pelaksanaan, dan evaluasi. Tahap persiapan merupakan kegiatan awal yang bertujuan menganalisis kebutuhan guru IPA, bahan pelatihan, dan perangkat evaluasi. Tahap kedua, kegiatan PKM difokuskan untuk mendampingi peserta menyusun instrumen penilaian sesuai dengan indikator yang telah disusun berdasarkan KD yang tertulis pada analisis situasi. Para peserta akan dibagi ke dalam beberapa kelompok kerja untuk melakukan workshop menyusun instrumen penilaian. Tahap terakhir ialah tahap evaluasi. Tahap ini dibagi dua, meliputi evaluasi tugas atau kemampuan peserta melalui tugas yang telah dikerjakan dan evaluasi kegiatan PKM melalui umpanbalik peserta pelatihan.

\section{HASIL DAN PEMBAHASAN}

Instrumen penilaian pengetahuan yang telah dikembangkan peserta pelatihan divalidasi menggunakan lembar validator dan dianalisis sesuai dengan skala Likert pada Tabel 2 sebagai berikut.

Tabel 2. Skala Penilaian Validator

\begin{tabular}{cc}
\hline Skor Validasi & Kriteria Penilaian \\
\hline 1 & Kurang baik \\
\hline 2 & Cukup baik \\
\hline 3 & Baik \\
\hline 4 & Sangat baik
\end{tabular}

(Diadaptasi dari riduawan, 2012) 
Data yang diperoleh dianalisis untuk masing-masing kelompok, nilai yang dituliskan untuk menentukan skor validasi instrumen penilaian yang telah dikembangkan ditentukan dengan nilai modus untuk keseluruhan ranah yang dinilai. Sehingga didapat data pada Tabel 3 sebagai berikut.

Tabel 3. Skor Penilaian Validasi

\begin{tabular}{clcc}
\hline Nama Kelompok & Instrumen Penilaiaan & Skor & Kategori \\
\hline Kel. 1 & Penilaian Pengetahuan & 4 & Sangat Baik \\
\hline Kel. 2 & Penilaian Pengetahuan & 4 & Sangat Baik \\
\hline Kel. 3 & Penilaian Pengetahuan & 4 & Sangat Baik \\
\hline Kel. 4 & Penilaian Pengetahuan & 4 & Sangat Baik \\
\hline
\end{tabular}

Nilai validasi yang diperoleh oleh empat kelompok adalah 4 dengan kategori sangat baik. Penilaian yang dilakukan menggunakan penilaian terhadap ranah materi, konstruksi dan Bahasa dari instrument penilaian yang dikembangkan oleh peserta. Nilai modus dari skor yang diberikan pada masing-masing ranah penilaian adalah 4 , jadi penilaian yang dikembangkan peserta memiliki kategori Sangat Baik. Penilaian ini bisa dijadikan acuan untuk dijadikan penilaian kompetensi pengetahuan sesuai dengan KD yang ditentukan.

Penilaian pencapaian kompetensi pengetahuan merupakan bagaian dari penilaian Pendidikan. Peraturan Menteri Pendidikan dan kebudayaan Nomor 66 Tahun 2013 tentang standart penilaian Pendidikan dijelaskan bahwa penilaian Pendidikan merupakan proses pengumpulan dan pengolahan informasi untuk mengukur pencapaian kompetensi peserta didik yang mencakup : penilaian otentik, penilaian diri, penilaian berbasis portofolio, ulangan harian, ulangan tengah semester, ulangan akhir semester, ujian tingkat kompetensi, ujian mutu tingkat kompetensi, ujian nasional, dan ujian sekolah. Penilaiaan pencapaian kompetensi peserta didik meliputi sikap, pengetahuan dan keterampilan yang dilakukan secara seimbang sehingga apat digunakan untuk menentukan posisi relative setiap peserta didik terhadap standar yang telah ditetapkan.

Penilaian pengetahuan juga dapat diartikan sebagai penilaian potensi intelektual yang terdiri dari tahapan mengetahui, memahami, menerapkan, menganalisis, mensitesis dan menevaluasi (Anderson \& Krathwohl, 2001). Sebagai guru perlu melakukan penilaian untuk mengetahui pencapaian kompetensi pengetahuan peserta didiknya. Penilaian pengetahuan ini dapat dilakukan melalui tes tulis, lisan dan penugasan. Kegiatan penilaian pengetahuan juga digunakan sebagai pemetaan kesulitan belajar yang dialami peserta didik dan perbaikan dalam proses pembelajaran yang dilakukan oleh guru.

Kompetensi inti yang harus dimiliki oleh peserta didik pada ranah pengetahuan adalah memahami pengetahuan (faktual, konseptual dan proedural) berdasarkan rasa ingin tahunya tentang ilmu pengetahuan, teknologi, seni dan budaya terkait fenomena dan kejadian tampak mata (Peraturan Menteri Pendidikan dan Kebudayaan Nomor 66 Tahun 2013).

Hasil dari pendampingan penyusunan instrumen penilaian oleh guru-guru IPA Kabupaten Banyuwangi adalah instrumen yang digunakan untuk mengukur pengetahuan peserta didik dan berjenis paper and pencil serta merupakan soal pilihan ganda. Penyusunan instrument penilaian yang dilakukan melalui tahapan menentukan kata kerja operasional yang ada dalam kompetensi dasar dan indikator pencapaian kompetensi yang dirumuskan.

Instrumen penilaian yang telah dikembangkan juga dilengkapi dengan kunci jawaban dan pedoman skor penilaian. Namun kekurangan dalam instrument yang dikembangkan belum dilengkapi dengan table kisi-kisi, dimana terdapat pelevelan ranah kognitif dari masing-masing soal yang digunakan sebagai instrument penilaian pengetahuan.

Pengembangan penilaian performance baced juga dikembangkan oleh beberapa kelompok. Kelompok yang mengembangkan instrumen ini adalah kelompok 1, 2 dan 4 . Namun penilaian untuk performance baced yang telah dikembangkan belum dapat dilakukan, karena peserta belum memberikan rubrik yang jelas untuk penilaian tersebut serta komponen yang jelas. Menurut Stiggins terdapat empat jenis metode penilaian dasar antara lain: selected responses assessment, 
essay assessment, performance assessment, personal communication assessment.

Perfomance baced yang telah dikembangkan peserta merupakan performance assessment yaitu pengukuran langsung terhadap prestasi yang ditunjukkan siswa dalam proses pembelajaran. Penilaian ini didasarkan pada kegiatan observasi dan evaluasi terhadap proses dimana suatu keterampilan, sikap dan produk ditunjukkan oleh siswa.

\section{Umpan-balik dari peserta pelatihan}

Umpan balik dari peserta pelatihan adalah hasil respon dari peserta PKM setelah pelatihan yang diberikan melalui tahapan persiapan dan pelaksanaan. Umpan balik ini didapat pada tahap evaluasi yaitu tahap terakhir dari pendampingan penyusunan instrumen penilaian yang telah dilakukan. Untuk mengetahui distribusi respon peserta diberikan angket respon pada Tabel 4.

Tabel 4. Respon Peserta Pendampingan Penyusunan Instrumen Penilaian

\begin{tabular}{|c|c|c|c|c|c|}
\hline \multirow{2}{*}{ No. } & \multirow{2}{*}{ Pernyataan } & \multicolumn{4}{|c|}{ Respon } \\
\hline & & STS & TS & $S$ & SS \\
\hline 1 & $\begin{array}{l}\text { Kegiatan pelatihan/pendampingan yang diberikan bermanfaat } \\
\text { untuk peningkatan kompetensi pedagogik guru. }\end{array}$ & $0 \%$ & $0 \%$ & $18 \%$ & $82 \%$ \\
\hline 2 & $\begin{array}{l}\text { Kegiatan pelatihan/pendampingan yang diberikan bermanfaat } \\
\text { untuk peningkatan kompetensi profesional guru. }\end{array}$ & $0 \%$ & $0 \%$ & $23 \%$ & $77 \%$ \\
\hline 3 & $\begin{array}{l}\text { Pelatihan analisis materi esensial memudahkan saya } \\
\text { menemukan poin-poin penting dari materi yang akan saya } \\
\text { ajarkan. }\end{array}$ & $0 \%$ & $0 \%$ & $43 \%$ & $57 \%$ \\
\hline 4 & $\begin{array}{l}\text { Pelatihan analisis materi esensial dapat membuat saya } \\
\text { terampil dalam menyusun indikator pencapaian kompetensi } \\
\text { (IPK). }\end{array}$ & $0 \%$ & $0 \%$ & $57 \%$ & $43 \%$ \\
\hline 5 & $\begin{array}{l}\text { Pelatihan penyusunan instrumen penilaian membantu saya } \\
\text { memahami bagaimana menyusun alat evaluasi pembelajaran } \\
\text { yang benar. }\end{array}$ & $0 \%$ & $0 \%$ & $55 \%$ & $45 \%$ \\
\hline 6 & $\begin{array}{l}\text { Materi pelatihan penyusunan instrumen penilaian dijelaskan } \\
\text { dengan contoh-contoh yang memudahkan saya untuk } \\
\text { menyusun alat evaluasi. }\end{array}$ & $0 \%$ & $0 \%$ & $52 \%$ & $48 \%$ \\
\hline 7 & $\begin{array}{l}\text { Materi pelatihan/pendampingan sudah sesuai dengan } \\
\text { harapan saya }\end{array}$ & $0 \%$ & $2 \%$ & $84 \%$ & $11 \%$ \\
\hline 8 & $\begin{array}{l}\text { Saya merasa tidak mendapat manfaat dari kegiatan } \\
\text { pelatihan/pendampingan ini. }\end{array}$ & $55 \%$ & $43 \%$ & $2 \%$ & $0 \%$ \\
\hline 9 & $\begin{array}{l}\text { Saya merasa kegiatan pelatihan/pendampingan tidak sesuai } \\
\text { dengan tujuan. }\end{array}$ & $48 \%$ & $52 \%$ & $0 \%$ & $0 \%$ \\
\hline 10 & $\begin{array}{l}\text { Metode yang digunakan dalam kegiatan } \\
\text { pelatihan/pendampingan sudah sesuai sehingga saya dapat } \\
\text { memperoleh banyak informasi/pengetahuan terkait } \\
\text { pengembangan perangkat pembelajaran }\end{array}$ & $0 \%$ & $0 \%$ & $80 \%$ & $20 \%$ \\
\hline 11 & $\begin{array}{l}\text { Metode yang digunakan dalam kegiatan } \\
\text { pelatihan/pendampingan ini membuat saya termotivasi untuk } \\
\text { mengikuti kegiatan hingga selesai. }\end{array}$ & $0 \%$ & $0 \%$ & $52 \%$ & $48 \%$ \\
\hline 12 & $\begin{array}{l}\text { Kegiatan pelatihan/pendampingan membuat saya lebih } \\
\text { percaya diri untuk melaksanakan proses belajar mengajar. }\end{array}$ & $0 \%$ & $2 \%$ & $66 \%$ & $32 \%$ \\
\hline 13 & $\begin{array}{l}\text { Kegiatan pelatihan/pendampingan membuat saya menjadi } \\
\text { guru IPA yang lebih kreatif. }\end{array}$ & $0 \%$ & $0 \%$ & $68 \%$ & $32 \%$ \\
\hline 14 & $\begin{array}{l}\text { Waktu yang disediakan untuk kegiatan pelatihan/ } \\
\text { pendampingan ini sudah sesuai dengan materi yang } \\
\text { diberikan. }\end{array}$ & $2 \%$ & $39 \%$ & $45 \%$ & $14 \%$ \\
\hline
\end{tabular}

Kegiatan pelatihan/pendampingan yang diberikan bermanfaat untuk peningkatan kompetensi pedagogik guru merupakan salah satu pertanyaan pada angket respon yang mendapatkan skor $82 \%$ untuk respon Sangat Setuju. Guru-guru IPA Kabupaten Banyuwangi juga menyampaikan bahwa pelatihan yang serupa sangat diminati oleh 
guru, karena dengan pelatihan para peserta yaitu guru mendapatkan informasi yang lebih untuk pengetahuan yang selama ini telah mereka miliki. Hasil wawancara dengan beberapa guru yang mengikuti pelatihan juga mendukung hasil tersebut. Namun ada pula peserta pelatihan yang menyatakan bahwa "Saya merasa tidak mendapat manfaat dari kegiatan pelatihan/pendampingan ini" dengan nilai $2 \%$. Hal ini dimungkinkan karena waktu pendampingan dan pelatihan yang singkat, sehingga peserta merasa masih belum dapat mengupgrade pengetahuan mereka dari apa yang telah diberikan oleh pemateri. Sehingga penilaian mereka untuk pertanyaan no.8 memilih Setuju jika tidak mendapat manfaat dari pendampingan yang dilakukan. Data ini diperkuat dengan data yang diperoleh dari respon untuk no.14 tentang waktu pendampingan, dimana peserta memberikan nilai 2\% untuk Sangat Tidak Setuju untuk pernyataan "Waktu yang disediakan untuk kegiatan pelatihan/ pendampingan ini sudah sesuai dengan materi yang diberikan".

Kendala dalam pendampingan penyusunan instrument penilaian di Kabupaten Banyuwangi secara teknis adaalah waktu, sehingga hasil respon untuk pernyataan ini memang kurang baik. Tim pendamping akan mengevaluasi hal ini supaya dalam kegiatan yang akan dating tidak terjadi lagi kekurangan waktu untuk materi yang akan disampaikan. Selain waktu jarak tempuh yang jauh merupakan kendala juga untuk pemateri, sehingga jarak atau tempat yang jauh memerlukan pengkodisian yang berbeda dengan tempat pelatihan yang dekat dengan Surabaya.

\section{SIMPULAN DAN SARAN}

Instrumen Penilaian yang dihasilkan dari 4 kelompok peserta pelatihan, yaitu: Kelompok 1 , kelompok 2, kelompok 3 dan kelompok 4 mendapatkan skor 4 untuk semua ranah validasi, sehingga instrument penilaian yang dikembangkan mendapat kategori Sangat Baik.
Respon peserta pelatihan terhadap kegiatan pelatihan, antara lain (1) untuk pernyataan tentang hubungan pemberian pendampingan dengan kompetensi pedagogik "Kegiatan pelatihan/pendampingan yang diberikan bermanfaat untuk peningkatan kompetensi pedagogik guru" pada angket respon mendapatkan skor $82 \%$ untuk respon Sangat Setuju, (2) pernyataan tentang manfaat pendampingan "Saya merasa tidak mendapat manfaat dari kegiatan pelatihan/pendampingan" ini memperoleh skor 2\% dengan respon Setuju, (3) pernyataan tentang waktu pelaksanaan pendampingan "Waktu yang disediakan untuk kegiatan pelatihan/ pendampingan ini sudah sesuai dengan materi yang diberikan" mendapatkan skor $2 \%$ untuk respon Sangat Tidak Setuju.

\section{DAFTAR PUSTAKA}

Anderson, L. W. And Krathwohl, D. R. 2001. A Taxonomy for Learning, Teaching, and Assessing. A Revision of Bloom's Taxonomy of Educational Objectives. New York. Addison Wesley Longman, Inc.

Kemendikbud, 2014b, Penilaian Pencapaian Kompetensi Peserta Didik Sekolah Menengah Pertama.

Peraturan Menteri Pendidikan dan Kebudayaan Republik IndonesiaNomor 66 Tahun 2013 tentang Standar Penilaian Pendidikan.

Riduwan. 2012. Belajar Mudah Penelitian Untuk Guru, Karyawan dan Peneliti Pemula. Bandung: Alfabeta.

Stiggins.et al. 1990. Observing Activities: Assesing Science in The Primary Classroom. London: Paul Chapman Publishing Ltd.

Surat Permohonan No 004/104.33/MGMP.IPA/III/2017 . 